\title{
GAYA KEPEMIMPINAN TRANSFORMASIONAL DAN TRANSAKSIONAL SERTA HUBUNGANNYA DENGAN KINERJA KARYAWAN (TINJAUAN TEORITIS DAN EMPIRIS)
}

\author{
I Wayan Gde Sarmawa \\ wayangdesarmawa@gmail.com \\ Fakultas Ekonomi dan Bisnis Universitas Warmadewa
}

\begin{abstract}
ABSTRAK
Gaya kepemimpinan adalah cara memberikan arahan, menerapkan strategi, dan memotivasi individu untuk mencapai tujuan yang diinginkan. Gaya kepemimpinan direplikasi dalam sikap dan perilaku tetapi pada gilirannya adalah hasil dari interaksi yang kompleks antara cara individu berpikir dan merasakan. Para peneliti menyoroti beragam pendekatan / gaya kepemimpinan yang didasarkan pada asumsi dan teori yang berbeda. Seiring berjalannya waktu, para analis telah bekerja untuk mengembangkan berbagai model, teori dan asumsi mengenai gaya kepemimpinan. Inti dari penelitian mereka adalah untuk menguraikan efektivitas kepemimpinan dalam organisasi/perusahaan termasuk pembentukan otoritas, mendorong rasa tanggung jawab, meminimalisasi dan mengatasi masalah karyawan dalam konteks situasi yang sudah berlaku. Dalam berbagai penelitian, di antara banyak gaya kepemimpinan, maka dua gaya kepemimpinan menjadi jauh lebih menonjol yaitu kepemimpinan transformasional dan transaksional. Kedua gaya ini telah dianalisis dalam berbagai sektor sosial-ekonomi dan akademik yang berbeda dengan keunggulannya masingmasing. Saat ini, kedua ditelaah dalam berbagai situasi yang berbeda serta hubungannya dengan kinerja karyawan.
\end{abstract}

Kata kunci: Kepemimpinan transformasional, Kepemimpinan transaksional, Kinerja karyawan

\section{PENDAHULUAN}

Pada situasi sekarang ini, institusi baik publik maupun swasta membutuhkan kepemimpinan baik transaksional atau transformasional berdasarkan kompetensi mereka (inovasi dan kreativitas) mencapai tugas pemulihan di lembaga-lembaga ini (Avolio \& Bass, 2004). Kepemimpinan yang kompeten dapat mewujudkan meminimalisasi, bahkan menghilangkan hambatan yang ada dalam organisasi/perusahaan. Kepemimpinan efektif mampu memfungsikan karyawan secara tepat, sehingga mendorong kemajuan organisasi/perusahaan (Avolio, Walumbwa \& Weber, 2009). Sejalan dengan itu, beberapa masalah seperti otoritas dan kinerja kepemimpinan, keterampilan komunikasi dan pengambilan keputusan, kemampuan intelektual dan karakteristik pribadi adalah inti kinematika di belakang. Kepemimpinan dan tenaga kerja mereka di bawahnya dijembatani oleh tingkat kinerja (Bass, Avolio, Jung \& Berson, 2012). Sejalan dengan itu, keberhasilan lembaga-lembaga ini hanya bertumpu pada kinerja karyawan dan kepemimpinan. Pada bagian dari karyawan upaya tanpa gentar mereka, ketekunan dan efisiensi mengarah ke tujuan yang diinginkan adalah replika berbagai gaya kepemimpinan (lqbal, Anwar \& Haider, 2015). Di antara gaya-gaya ini, yang paling menonjol adalah kepemimpinan transformasional dan transaksional.

Penelitian ini adalah upaya progresif untuk mengembangkan kerangka teori yang dapat memberikan dasar yang kuat bagi peneliti untuk menerapkan teori yang muncul dari teori yang sudah ada. Teori-teori ini secara total tidak dapat diimplementasikan dalam konteks apa pun. 
Untuk tujuan ini, peneliti menganalisis secara menyeluruh teori-teori kepemimpinan yang menonjol, gaya kepemimpinan, model terkait mereka dan status lembaga dalam keadaan yang beragam. Pekerjaan ini adalah upaya untuk membangun model kepemimpinan di mana gaya kepemimpinan (transformasional dan transaksional) bertindak sebagai prediktor untuk kinerja karyawan. Kami mencari pemimpin seperti itu yang secara komprehensif menginvestigasi hambatan dalam peningkatan kelembagaan, rintangan politik dan birokrasi, korupsi di dalam dan mencari langkah-langkah yang sesuai melalui kompetensi dan pengalaman mereka untuk meningkatkan tingkat kinerja karyawan. Dalam hal ini, studi saat ini adalah tinjauan komprehensif literatur tentang gaya kepemimpinan (transformasional dan transaksional) dan kinerja karyawan.

\section{TINJAUAN PUSTAKA}

Gaya kepemimpinan dapat meningkatkan atau mengurangi tingkat kinerja karyawan yang bekerja di bawah pengawasan langsungnya. Sejauh mana, hubungan ini efektif sehubungan dengan kepemimpinan transformasional atau transaksional adalah tema utama penelitian ini. Ada kerumitan tertentu dalam menguraikan tingkat kinerja karena ini adalah fenomena multi-dimensi yang harus dijabarkan dengan cermat. Tema utama kinerja terletak pada saling ketergantungan dari beberapa parameter yang saling terkait agak sangat terkait satu sama lain. Dalam penelitian ini, parameter utama berkenaan dengan kinerja (dependen) adalah gaya kepemimpinan (transformasional \& transaksional) dan atribut pribadi yaitu demografi. Semua ini, memberikan dasar yang kuat untuk membangun kinerja dan pada gilirannya berupa output dari para karyawan di organisasi/perusahaan yang bersangkutan..

\subsection{Kepemimpinan}

Struktur organisasi terdiri dari sejumlah departemen yang berbeda di mana karyawan bekerja sebagai unit dasar dengan kapasitas yang berbeda-beda. Dalam hal ini, tanggung jawab mendasar seorang kepemimpinan adalah untuk meningkatkan nilai-nilai moral, kapasitas kerja dan pada akhirnya meningkatkan kinerja organisasi (Avolio \& Bass, 2004). Para karyawan, di hadapan kepemimpinan mungkin tidak merasa terisolasi dari otoritas pusat yang membuat mereka tetap utuh dan akibatnya mereka bekerja dengan integritas dan komitmen penuh. Pada tingkat makroskopik, kepemimpinan adalah bidang penelitian dan keterampilan praktis (King, Johnson \& Vugt, 2009). Pada tulisan ini, peneliti menyoroti gaya kepemimpinan yang berbeda dalam keadaan yang berbeda di berbagai bidang kehidupan. Pada bagian tingkat individu, kepemimpinan mencakup kemampuan, kapasitas memimpin, keterampilan dan pengalaman seseorang pemimpin dalam memimpin sekelompok orang (Tahir, Abdullah, Ali \& Daud, 2014). Sementara menjalankan wewenang, kepemimpinan berusaha mencari partisipasi karyawan dengan semua dedikasi dan rasa kepemilikan mereka melalui kekuatan mobilisasi, motivasi dan komunikasi dalam organisasi (Chandra \& Priyono, 2016).

\subsection{Gaya Kepemimpinan Kepemimpinan}

\subsubsection{Transformasional Pemimpin}

Kepemimpinan Transformasional adalah kepemimpinan yang memiliki kemampuan karismatik, menginduksi nilai-nilai moral dan mengembangkan kemampuan karyawan ke arah yang lebih baik. Kepemimpinan ini memberikan semacam visi yang mengangkat potensi kerja dan komitmen para pengikut/karyawan untuk menyelesaikan tugas-tugas dengan baik, dan akhirnya menghasilkan output maksimum (Avolio \& Bass, 2004). Akibatnya, karyawan mengedepankan segala kemampuan mereka untuk meningkatkan kinerja mereka melebihi standar yang ditetapkan. Pada saat yang sama, kepemimpinan transformasional mendorong inovatif, kreatif sampai batas tertentu,serta berani mengambil inisiatif serta berkolaborasi secara kuat untuk kemajuan organisasi (Salman, Riaz, Saifullah \& Rashid, 2011). 
Tugas utama seorang pemimpin transformasional adalah membangun kerangka kerja struktur organisasi sesuai dengan perkembangan dan keinginan karyawan dengan tetap memperhatikan standar global dan perubahan situasi. Pemimpin transformasional menumbuhkan tingkat kepercayaan di antara karyawan, selanjutnya mengakumulasi nilai-nilai pemikiran karyawan untuk menghasilkan kinerja yang lebih baik (Chandra \& Priyono, 2016). Ada empat atribut dalam gaya kepemimpinan transformasional yaitu pengaruh ideal, pertimbangan individual, motivasi inspirasional dan stimulasi intelektual.

\subsubsection{Kepemimpinan Transaksional}

Penelitian ini berusaha memberikan argumentasi sejauh mana hubungan gaya kepemimpinan transformasional dan transaksional dengan kinerja karyawan. Pada saat yang sama, juga memberikan argumentasi dampak kepemimpinan transaksional dalam hubungannya dengan kinerja karyawan. Pemimpin transaksional, adalah pemimpin yang menerapkan menerapkan aturan dan peraturan, menetapkan wewenang tertulis, menetapkan dan berfokus pada tujuan tertentu, mengarahkan karyawan untuk mencapai tugas yang ditentukan sebelumnya (Avolio \& Bass, 2004).

Selama perjalanan waktu, keterampilan dan pengalaman karyawan digunakan secara maksimal melalui sistem penghargaan bagi karyawan yang menunjukkan kinerja baik, dan hukuman untuk karyawan yang kinerjanya kurang/tidak (Udoh \& Agu, 2012). Seluruh fenomena ini direntang bukan dalam jangka waktu yang lama, melainkan profil organisasi menjadi berorientasi ulang dan seluruh dinamika disesuaikan dengan standar yang diinginkan. Keseluruhan ini dibuat dalam suatu aturan secara tertulis, untuk ditaati oleh seluruh karyawan. Kepemimpinan transaksional secara ketat menerapkan aturan-aturan ini, dengan tujuan agar karyawan menunjukkan kinerja secara maksimal (Shah \& Kamal, 2015). Terdapat empat atribut gaya kepemimpinan transaksional yaitu imbalan bersyarat (contingent reward), hukuman bersyarat (contingent punishment), manajemen-dengan-pengecualian/management by exeption (aktif) dan manajemen-oleh-pengecualian/management by exeption (pasif).

\subsection{Kinerja Karyawan}

Istilah kinerja didefinisikan sebagai kemampuan utama seorang individu (karyawan) untuk menggunakan pengetahuan dan keterampilannya secara efisien dan efektif. Sejauh ini, menurut sejumlah hasil penelitian, kinerja karyawan sangat terkait dengan profil fisik dan akademiknya (Dvir, Eden, Avolio \& Shamir, 2002). Dalam hal ini, kinerja karyawan paling signifikan untuk menghasilkan hasil sesuai dengan standar internasional. Kinerja individu semata-mata tergantung pada kebijakan lembaga yang berkaitan dengan paket gaji, hadiah, bonus, kenaikan tahunan dan tunjangan serta hak istimewa lainnya (Bodla \& Nawaz, 2010). Namun, profil akademik karyawan memiliki posisi tertinggi di antara semua faktor lainnya. Secara keseluruhan, produktivitas / output dapat ditingkatkan dan dipertahankan oleh efektivitas kepemimpinan dan kecepatan respons dari karyawan (Rizwan, Nazar, Nadeem \& Abbas, 2016).

Di satu sisi, gaya kepemimpinan menginduksi kekuatan emosional, motivasi, komitmen, dan hubungan kerja sementara di sisi lain, karyawan melakukan dengan kemampuan dan ketekunan terbaik mereka. Atribut utama yang berkaitan dengan kinerja karyawan dalam sejumlah literatur yang relevan adalah efisiensi, efektivitas, inovasi, daya tanggap. Terdapat sejumlah atribut lain yang terkait dengan kinerja karyawan yaitu etika kerja, komunikasi, kreativitas, pengembangan, profesionalisme dan komitmen. Semua atribut ini berkontribusi secara efektif pada kinerja karyawan.

\subsection{Kepemimpinan dan Kinerja Karyawan}

Untuk meningkatkan kinerja karyawan, ketergantungannya pada kepemimpinan, yang operatif, memiliki status yang pasti. Dalam fenomena yang sama, peran sentral kepemimpinan beserta kredibilitasnya menjadi yang paling menonjol (Bass, Avolio, Jung \& Berson, 2003). 
Sebenarnya, pemimpin transformasional adalah seorang psikoanalis, ketika dia belajar, memahami dan menganalisis pikiran, pikiran, sikap dan keinginan para pengikut / karyawan untuk mencapai keputusan akhir yang membantu dalam meningkatkan tingkat kinerja karyawan (Qaisar \& Sara, 2009). Kepemimpinan dari kategori ini selalu mengedepankan demokratisasi dan rasa saling percaya untuk menyelesaikan setiap masalah dalam organisasi sesuai dengan kehendak sebagian besar karyawan. Keterampilan diagnostik kepemimpinan, sangat berharga untuk menyelesaikan masalah yang terkait dengan individu dan dengan organisasi secara keseluruhan (Durga \& Prabhu, 2011). Kinerja karyawan berbanding lurus dengan efektivitas kepemimpinan. Melalui kekuatan pemahaman, analisis, perencanaan dan motivasi, para pemimpin transformasional mampu meningkatkan hasil kerja karyawan (lqbal et al., 2015; Jangsiriwattana, 2019; Nsom et al., 2019). Berdasarkan paparan sebagaimana telah dikemukakan maka banagunan kerangka secara teoritis dapat digambarkan sebagai berikut:

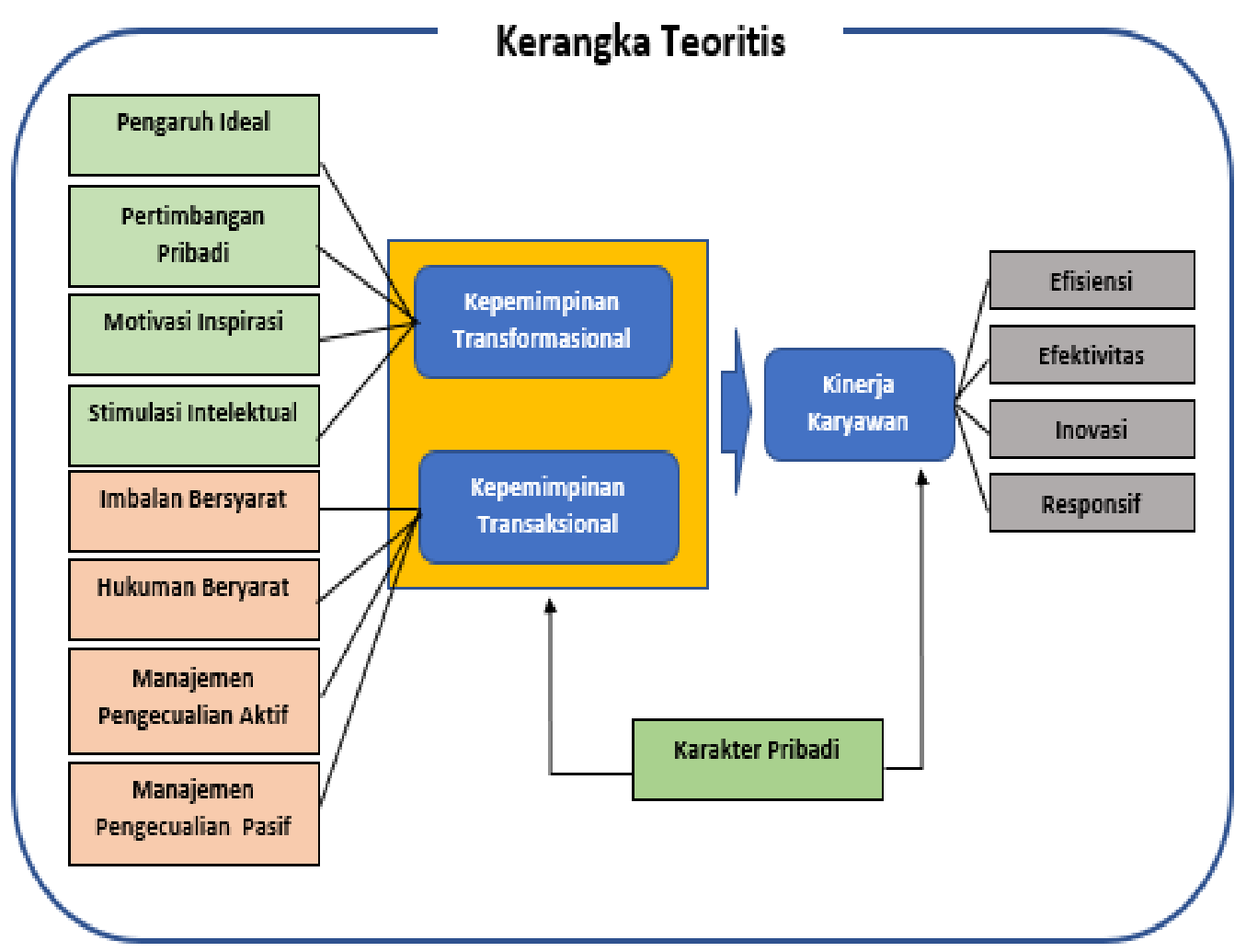

Gambar 1. Kerangka Teoritis

\section{DISKUSI}

Dalam lingkungan persaingan kontemporer, kelangsungan hidup dan pengembangan organisasi/perusahaan diperlukan gaya kepemimpinan yang mampu memainkan peran utama dalam meningkatkan kinerja mereka. Dalam situasi yang berlaku, tujuan utama untuk setiap organisasi/perusahaan dinamis adalah pengembangan kemampuan individu dan pada akhirnya kinerja lembaga (Dvir, Eden, Avolio \& Shamir, 2002). Kinerja karyawan adalah ringkasan perilaku individu yang berkontribusi terhadap realisasi tujuan organisasi/perusahaan. Saat ini, para peneliti memperhitungkan banyak faktor untuk memperbaiki kinerja karyawan, salah satumya termasuk kepemimpinan. Faktor lain juga mendapat sorotan yaitu kondisi kerja, hubungan kolega, promosi, upah, keamanan kerja, pengawasan karakteristik pribadi, motivasi, kesetaraan, 
faktor kepribadian dan struktur organisasi (Smerek \& Peterson, 2006). Jelas, ada kebutuhan untuk meningkatkan kinerja karyawan untuk membawa perubahan positif dengan penerimaan mekanisme untuk mengembangkan kinerja organisasi/perusahaan (Salman, Riaz, Saifullah \& Rashid, 2011).

Oleh karena karakteristiknya yang populer, maka kepemimpinan transformasional menempati posisi tinggi di antara semua teori kepemimpinan. Dalam situasi yang ada, keberhasilan gaya keemimpinan ini adalah karena kedekatan yang erat dalam semua hal antara pemimpin dengan bawahannya/karyawannya. Format gaya kepemimpinan terutama bertumpu pada tingkat kepercayaan, motivasi yang mengarah ke sistem desentralisasi di mana seorang individu dapat melakukan secara maksimal melebihi kepentingan pribadi apa yang pernah terjadi (Udoh \& Agu, 2012). Kecakapan para pemimpin untuk secara akurat mempraktikkan gaya transformasional dalam mengelola tugas-tugas organisasi dapat memengaruhi kinerja karyawan. Dengan cara memimpin karyawan, pemimpin dengan gaya kepemimpinan transformasional dapat dicirikan sebagai mengidealkan atribut / perilaku yang mempengaruhi, menginspirasi motivasi karyawan, mendorong stimulasi intelektual dan pertimbangan individual (Tahir, Abdullah, Ali \& Daud, 2014). Berbeda dengan kepemimpinan transformasional yang bekerja atas kemauan karyawan dengan fleksibilitas maksimal sehingga kepemimpinan transaksional melampaui apa yang ditulis dalam aturan organisasi/perusahaan.

Kepemimpinan transaksional menggambarkan ikatan antara karyawan dan pemimpin dalam hal pertukaran nilai-nilai psikologis dan ekonomi. Para pemimpin transaksional umumnya mencerminkan bagaimana mengembangkan dan mempertahankan standar kinerja, bagaimana tindakan spesifik dalam mengurangi konflik, bagaimana mengganti satu tujuan dengan tujuan yang lain dan bagaimana menerapkan keputusan tersebut (Saqib et al, 2015). Pemimpin transaksional melibatkan pengikut mereka dalam afiliasi ketergantungan bersama di mana pengaruh kedua belah pihak diakui. Gaya akepemimpinan seperti saangat efektif dalam situasi ini karena melakukan apa yang dibutuhkan para pemimpin adalah demi kepentingan terbaik karyawan. Pemimpin transaksional sangat menyadari harapan karyawan/pengikut mereka (Chandra \& Priyono, 2016). Oleh karena itu, kepemimpinan transaksional bergantung pada kemampuan pemimpin untuk bertemu dan menanggapi keinginan karyawan mereka. Kepemimpinan transaksional adalah substansi dari motivasi ekstrinsik, tahan perubahan, penguatan kontingen dan meminimalisasi hasil kinerja yang buruk.

Penelitian ini adalah upaya untuk mengeksplorasi gaya kepemimpinan yang sesuai (transformasional \& transaksional) sehubungan dengan kinerja karyawan. Kedua gaya ini memiliki dampak signifikan pada kinerja individu. Namun, ketika para pemimpin mengadaptasi gaya kepemimpinan transformasional maka itu tidak berarti mereka tidak memberikan penghargaan kepada karyawan yang berkinerja lebih baik. Di sisi lain, jika para pemimpin mengadaptasi gaya transaksional maka itu juga tidak berarti mereka tidak memotivasi dan mendorong karyawan mereka. Ini berarti bahwa setiap pemimpin memiliki atribut kepemimpinan transformasional dan transaksional. Jika pemimpin mengadaptasi gaya transformasional, maka itu tidak berarti mereka tidak mengikuti aturan dan regulasi. Di sisi lain, jika pemimpin mengadaptasi gaya transaksional maka itu tidak berarti bahwa mereka tidak memotivasi dan menginspirasi karyawan mereka. Jadi ada kebutuhan gaya kepemimpinan bersama yang berisi campuran atribut dari kedua gaya kepemimpinan tersebut. Oleh karena itu, penerapan gaya kepemimpinan transformasional dan transaksional adalah saling melengkapi satu dengan yang lainnya. Tentu penerapan gaya kepemimpinan transformasional maupun transaksional sesuai dengan kebutuhan situasi dan kondisi yang sedang dihadapi. 


\section{DAFTAR PUSTAKA}

Avolio, BJ, Walumbwa, J., \& Weber, TJ (2009). Kepemimpinan: Teori Saat Ini, Penelitian, dan Arah Masa Depan. Ulasan Tahunan Psikologi, 60.421-49.

Avolio, B., \& Bass, B. (2004). Kuisioner Kepemimpinan Multifactor: Manual Edisi Ketiga dan Perangkat Sampler, Mind Garden Inc., Palo Alto, CA.

Bass, BM, Avolio, BJ, Jung, DI, \& Berson, Y. (2012). Memprediksi kinerja unit dengan menilai kepemimpinan transformasional dan transaksional. Jurnal Psikologi Terapan, 88 (2), 207-218.

Bass, BM, Avolio, BJ, Jung, DI, \& Berson, Y. (2012). Memprediksi kinerja unit dengan menilai kepemimpinan transformasional dan transaksional. Jurnal Psikologi Terapan, 88 (2), 207-218.

Bodla, MA, \& Nawaz, M. (2010). Studi Banding Model Kepemimpinan Rentang Penuh di antara Anggota Fakultas di Institut dan Perguruan Tinggi Sektor Publik dan Swasta. Jurnal Internasional Bisnis dan Manajemen, 5 (4).

Chandra, T., \& Priyono, L. (2016). Pengaruh Gaya Kepemimpinan, Lingkungan Kerja dan Kepuasan Kerja terhadap Kinerja Karyawan. Studi Pendidikan Internasional, 9 (1), 131-140.

Durga, DP, \& Prabhu, N. (2011). Hubungan antara Kepemimpinan yang Efektif dan Kinerja Karyawan. Konferensi Internasional tentang Kemajuan Teknologi Informasi, 20, 198-207.

Dvir, T., Eden, D., Avolio, BJ, \& Shamir, B. (2002). Dampak kepemimpinan transformasional pada pengembangan dan kinerja pengikut: Eksperimen lapangan. Academy of Management Journal, 45 (4), 735-44.

lqbal, N., Anwar, S., \& Haider, N. (2015). Pengaruh Gaya Kepemimpinan terhadap Kinerja Karyawan. Jurnal Bisnis Arab dan Ulasan Manajemen, 5 (5).

Jangsiriwattana T. (2019). The Relationship Between Transformational And Transactional Leadership:Employee Perceptions Of Organizational Performanceandwork Engagement, Journal of the International Academy for Case Studies, Volume 25, Issue 3, pp. 1-10

King, A, J, Johnson, D, P., \& Vugt, MV (2009). Asal-usul dan evolusi kepemimpinan. Biologi Saat Ini, 19, 911-916.

Nsom N.K., Teih M.M., Sundjo F. (2019). The Effects Of Transactional And Transformational Leadership On Personnel Conduct, International Journal Of Research -Granthaalayah, 7(6),155164

Qaisar, A., \& Sara, Y. (2009). Pengaruh pengembangan kepemimpinan terhadap kinerja karyawan di Pakistan. Tinjauan Ekonomi dan Sosial Pakistan, 47 (2), 269-292.

Rizwan, M., Nazar, K., Nadeem, B., \& Abbas, Q. (2016). Dampak Keanekaragaman Tenaga Kerja terhadap Kinerja Karyawan. American Journal of Marketing Research, 2 (2), 53-60.

Salman, Z., Riaz, A., Saifullah, M., \& Rashid, M. (2011). Gaya Kepemimpinan dan Kinerja Karyawan. Jurnal Interdisipliner Penelitian Kontemporer dalam Bisnis. 3 (6), 257-267. 
Saqib, MK, Irfan, Inggris, Qamar, AQ, Farooq, J. (2015). Keragaman dalam Gaya Kepemimpinan: Pandangan Global. Manajemen Informasi dan Pengetahuan, 5 (1), 48-51.

Shah, M., \& Kamal, H. (2015). Kepemimpinan Transaksional dan Kinerja Pekerjaan: Investigasi Empiris. Institut Administrasi Bisnis, 2 (2), 69-81.

Smerek, RE, \& Peterson, M. (2006). Meneliti Teori Herzberg: meningkatkan kinerja di kalangan staf non-akademik di sebuah universitas. Penelitian dalam Pendidikan Tinggi, 48 (2), 229-250.

Tahir, L., Abdullah, T., Ali, F., \& Daud, K. (2014). Kepemimpinan transformasional akademik: penyelidikan perilaku kepala departemen kepemimpinan di Universitas Negeri Malaysia. Studi Pendidikan, 40, 473-495.

Udoh, BE, \& Agu, O. (2012). Dampak Kepemimpinan Transformasional dan Transaksional terhadap Kinerja karyawan. International Journal of Current Research, 4 (11), 142-147. 